\title{
Scaling up Primary Health Care in the Philippines: Lessons from a Systematic Review of Experiences of Community-based Health Programs
}

\author{
Edna Estifania A. Co, ${ }^{1}$ Ruben N. Caragay, ${ }^{2}$ Jaifred Christian F. Lopez,,${ }^{3,4}$ Isidro C. Sia, ${ }^{5}$ Leonardo R. Estacio, ${ }^{6}$ \\ Hilton Y. Lam, ${ }^{7}$ Jennifer S. Madamba, ${ }^{8}$ Regina Isabel B. Abola ${ }^{7}$ and Maria Fatima A. Villena ${ }^{8}$ \\ ${ }^{1}$ Center for Integrative and Development Studies, University of the Philippines System \\ ${ }^{2}$ College of Medicine, Bicol University, Albay \\ ${ }^{3}$ Office of Research and Innovation, and College of Medicine, San Beda University, Manila \\ ${ }^{4}$ Tambalista, Inc., Quezon City, Philippines \\ ${ }^{5}$ College of Medicine, University of the Philippines Manila \\ ${ }^{6}$ College of Arts and Sciences, University of the Philippines Manila \\ ${ }^{7}$ Institute of Health Policy and Development Studies, National Institutes of Health, University of the Philippines Manila \\ ${ }^{8}$ Emerging Interdisciplinary Research, University of the Philippines System
}

\begin{abstract}
Background. In view of renewed interest in primary health care (PHC) as a framework for health system development, there is a need to revisit how successful community health programs implemented the PHC approach, and what factors should be considered to scale up its implementation in order to sustainably attain ideal community health outcomes in the Philippines.
\end{abstract}

Objective and methodology. Using the 2008 World Health Report PHC reform categories as analytical framework, this systematic review aimed to glean lessons from experiences in implementing PHC that may help improve the functioning of the current decentralized community-level health system in the country, by analyzing gathered evidence on how primary health care evolved in the country and how community health programs in the Philippines were shaped by the PHC approach.

Results. Nineteen (19) articles were gathered, 15 of which documented service delivery reforms, two (2) on universal coverage reforms, three (3) on leadership reform, and one (1) on public policy. The literature described how successful PHC efforts centered on community participation and empowerment, thus pinpointing how community empowerment still needs to be included in national public health thrusts, amid the current emphasis on performance indicators to evaluate the success of health programs.

Conclusion and recommendations. The studies included in the review emphasize the need for national level public health interventions to be targeted to community health and social determinants of health as well as individual health. Metrics for community empowerment should be developed and implemented by government towards sustainable health and development, while ensuring scientific validity of community health interventions.

Key Words: community empowerment, community health programs, community participation, government, Philippines, primary health care

\section{INTRODUCTION}

In 1978, the International Conference on Primary Health Care, held in Alma Ata, Kazakhstan, gathered health decision makers from around the world and produced a landmark declaration that defined primary health care (PHC)

Corresponding author: Jaifred Christian F. Lopez, MD, MPM c/o Philippine Society of Public Health Physicians (PSPHP), Inc. Room 406 Veria 1 Building,

\#62 West Avenue, Barangay West Triangle,

Quezon City, Philippines 1104

Email: jaifredlopez@gmail.com as health care which is "based on practical, scientifically sound, and socially acceptable methods and technology, made universally accessible to individuals and families in the community through their full participation [...] in the spirit 
of self-reliance and self-determination," and committed a concerted global effort to achieve "health for all by the year 2000." Notably, this definition was influenced by experiences in China, Eastern Europe, Sub-Saharan Africa, South Asia, Southeast Asia, and Latin America, which had been encapsulated as a public health strategy through various fora and assemblies organized by the World Health Organization (WHO) and the United Nations Children's Fund (UNICEF) in the 1970s. ${ }^{2}$ However, the implementation of the Alma Ata Declaration faced political and economic challenges, and gave way for more pressing global health challenges that led to an emphasis on disease-specific health interventions, termed as "selective primary health care." ${ }^{3,4}$ Eventually, mounting evidence on socioeconomic and political factors contributory to the persistence of poor health outcomes, collectively termed as the social determinants of health, has propelled the World Health Organization (WHO) to revisit PHC as a paradigm for addressing health issues at a global scale, initially doing so in 1988 as it reflected on the prospects of achieving the Declaration's stated goal of "health for all" by 2000.,

As the Declaration reached its deadline, a renewal of its commitments was advocated during the 2000 People's Health Assembly held in Dhaka, Bangladesh, when health advocacy groups from all over the world gathered to reexamine the Declaration's level of accomplishment. ${ }^{7}$ This assembly then led to a "Health Care for All" declaration penned in 2001 by representatives of member states of the European Union and some African countries. ${ }^{8}$ Finally, in 2008, 30 years after the Alma Ata Declaration, the WHO attempted to provide an updated context to the original PHC definition by entitling its annual World Health Report (WHR) as "Primary Health Care - Now More Than Ever," which balanced its ongoing focus on disease-specific programs with recommendations for reform in public policy, leadership, service delivery and universal coverage. ${ }^{9} \mathrm{WHO}$ has since advocated for a "health in all policies" approach which recognizes the contribution and accountability of non-health sectors, such as agriculture and public works, towards addressing health needs and improving health outcomes. This approach, adopted during the 2013 Global Conference on Health Promotion in Helsinki, Finland, specifically encourages policy makers to reflect on the "health implications of decisions," while considering the social determinants of health. ${ }^{10}$

Nonetheless, just as how WHO revisited PHC by reviewing its historical and socioeconomic contexts, implementing this renewal of commitment to $\mathrm{PHC}$ in the Philippines would likewise require insightful consideration of how it was advocated and implemented in past decades. Since PHC is dependent on the concepts of social acceptability and community participation, it is likewise necessary to assess whether the proposed reforms of the renewed PHC approach are applicable to the Philippine situation. There is also a need to analyze how PHC can aid in addressing current health challenges, by considering how it influenced strategies developed in the past, especially at the community level. Analyzing these developments using a community-oriented lens is critical since the Philippine health care system relies on its most basic units, the barangay health stations and health centers, in addressing the health needs of millions of Filipinos.

Therefore, this study aimed to gather evidence on how primary health care evolved in the country and how community health programs in the Philippines were shaped by the PHC approach. This paper also aimed to glean lessons and identify gaps from these experiences that may help improve the functioning of the current decentralized community-level health system in the country, using the 2008 PHC reform categories as analytical framework.

\section{METHODS}

Systematic review of literature gathered from local and international sources was carried out, with each study categorized according to the type of $\mathrm{PHC}$ reform, as defined in the 2008 WHR. PubMed and Google Scholar were used to retrieve journal articles and grey literature, using keywords such as 'health and community', 'community participation in health', 'community-based health programs', and 'local health system.' In addition, local studies gathered from the University of the Philippines Manila College of Public Health Library, the Council for Health and Development (CHD), and the Integrative Medicine for Alternative Health Care Systems, Inc. (INAM Philippines) were also included. The systematic review only included studies that discussed multisectoral public health interventions and communitybased health programs (CBHPs) using the PHC approach at the community level in the Philippines, and excluded those which focused on a single disease intervention, health profession (i.e. health professions students, physicians, nurses, and midwives), or health information system. Articles without an abstract or full text were also excluded. A total of 19 articles were included in this review, after sifting through an initial result of 1,267 articles. The definitions used in analyzing the articles are shown in Table 1.

\section{RESULTS}

Most of the included articles (15 of 19) were case studies that chronicled milestones in service delivery reform, specifically promoting community participation in decision making for public health interventions, training community health workers, and providing community-based access to health facilities and medicines. There were also two (2) studies that dealt with promoting universal coverage at the community level, and one (1) study that enumerated public policy interventions implemented in two local government units (LGUs) that cut across various sectors that helped improve health outcomes. In addition, three (3) studies on leadership reform focused on the national government's efforts in scaling up the implementation of $\mathrm{PHC}$ to all villages 
nationwide. A summary of the systematic review is shown in Table 2. An important limitation of this study is that the review did not include multisectoral PHC efforts initiated by NGOs and advocacy groups that were familiar to the authors, since accounts of these efforts were not encountered despite our best effort to search the academic literature.

\section{Service delivery reforms}

Service delivery reform efforts documented in the literature concentrated on community engagement and empowerment initiated by government, private, faith-based, and foreign stakeholders, the provision of health services, and the training of health workers.
Efforts in improving health service delivery mostly aimed at multiple health needs, the most common of which were family planning, nutrition, sanitation, immunization, and the control of soil-transmitted helminth infections. ${ }^{11-15}$ These health needs were addressed by NGO-initiated efforts by constructing health facilities, providing access to medicines and services of health professionals, and training volunteer health workers, who were given various names such as katiwala (Filipino for "a trusted person"), and currently, barangay (Filipino for "village") health workers (BHWs) for government health programs and community health workers (CHWs) for NGO programs. ${ }^{11}$ The BHW was envisioned as a community health advocate facilitating access to local

Table 1. Four sets of primary health care reforms included in the 2008 World Health Report (WHR)

\begin{tabular}{ll}
$\begin{array}{l}\text { Reform category } \\
\text { Leadership reforms }\end{array}$ & $\begin{array}{l}\text { Definition (from the 2008 WHR) } \\
\text { disengagement of the state on the other, by the inclusive, participatory, negotiation-based leadership required } \\
\text { by the complexity of contemporary health systems }\end{array}$ \\
\hline Public policy reforms & $\begin{array}{l}\text { reforms that secure healthier communities, by integrating public health actions with primary care and by } \\
\text { pursuing healthy public policies across sectors }\end{array}$ \\
\hline Service delivery reforms & $\begin{array}{l}\text { reforms that reorganize health services as primary care, i.e. around people's needs and expectations, so as to } \\
\text { make them more socially relevant and more responsive to the changing world while producing better outcomes }\end{array}$ \\
\hline Universal coverage & $\begin{array}{l}\text { reforms that ensure that health systems contribute to health equity, social justice and the end of exclusion, } \\
\text { primarily by moving towards universal access and social health protection }\end{array}$ \\
\hline
\end{tabular}

Table 2. Results of the systematic review (studies arranged in chronological order)

\begin{tabular}{|c|c|c|c|c|c|}
\hline $\begin{array}{l}\text { Year/s of } \\
\text { implementation }\end{array}$ & $\begin{array}{l}\text { Description of } \\
\text { program/intervention }\end{array}$ & $\begin{array}{l}\text { Locale/ scope } \\
\text { of study }\end{array}$ & $\begin{array}{l}\text { Implementing } \\
\text { agency/ies }\end{array}$ & $\begin{array}{l}\text { Type of } \\
\text { PHC policy } \\
\text { reform* }\end{array}$ & $\begin{array}{c}\text { Study (first } \\
\text { author, year } \\
\text { of publication, } \\
\text { citation) }\end{array}$ \\
\hline 1950-1956 & $\begin{array}{l}\text { Review of community development training } \\
\text { programs, of which health was included as a } \\
\text { topic. The government implementation of a } \\
\text { Community Development Planning Council } \\
\text { was also mentioned, as inspired by an NGO } \\
\text { initiative }\end{array}$ & $\begin{array}{l}\text { Pangasinan, } \\
\text { National }\end{array}$ & $\begin{array}{l}\text { UNESCO, Philippine } \\
\text { Bureau of Public } \\
\text { Schools, Philippine } \\
\text { Rural Reconstruction } \\
\text { Movement, Philippine } \\
\text { Government }\end{array}$ & $\begin{array}{l}\text { Service } \\
\text { delivery }\end{array}$ & $\begin{array}{l}\text { Morgan, } \\
1965^{29}\end{array}$ \\
\hline 1960s-1980s & $\begin{array}{l}\text { Review of case studies discussing the } \\
\text { involvement of non-government organizations } \\
\text { in developing PHC }\end{array}$ & National & $\begin{array}{l}\text { Rights-based and } \\
\text { progressive advocacy } \\
\text { groups, religious } \\
\text { organizations }\end{array}$ & $\begin{array}{l}\text { Service } \\
\text { delivery }\end{array}$ & $\begin{array}{l}\text { Encarnacion } \\
\text { Tadem, } \\
2014^{17}\end{array}$ \\
\hline 1968 & $\begin{array}{l}\text { Case study of the implementation of the } \\
\text { Katiwala voluntary health service project. } \\
\text { Mothers served as "motivators" for } \\
\text { immunization, family planning and sanitation }\end{array}$ & $\begin{array}{l}\text { Eight provinces } \\
\text { and } 2 \text { cities in } \\
\text { Mindanao }\end{array}$ & $\begin{array}{l}\text { Davao Medical } \\
\text { School Foundation }\end{array}$ & $\begin{array}{l}\text { Service } \\
\text { delivery }\end{array}$ & $\begin{array}{l}\text { Angeles, } \\
1981^{11}\end{array}$ \\
\hline 1979 & $\begin{array}{l}\text { Case study of the } \mathrm{MOH} \text { adopting a } \\
\text { coordinating role in promoting } \mathrm{PHC} \text {, rather } \\
\text { than implementation }\end{array}$ & National & $\begin{array}{l}\text { Ministry of Health } \\
(\mathrm{MOH})^{\wedge}\end{array}$ & Leadership & $\begin{array}{l}\text { Bautista, } \\
1996^{23}\end{array}$ \\
\hline $1979-1980$ & $\begin{array}{l}\text { Case study documenting the implementation of } \\
\text { the Sarikaya project, where volunteers receive } \\
\text { training to carry out various public health } \\
\text { activities related to nutrition, reproductive } \\
\text { health, infection control, and sanitation. }\end{array}$ & National & Ministry of Health^ & $\begin{array}{l}\text { Service } \\
\text { delivery }\end{array}$ & $\begin{array}{l}\text { Marfil, } \\
1979^{12}\end{array}$ \\
\hline 1981 & $\begin{array}{l}\text { Case study of two primary health care projects } \\
\text { focusing on development and self-reliance. }\end{array}$ & $\begin{array}{l}\text { Sudtunggan and } \\
\text { Consolacion, } \\
\text { Cebu }\end{array}$ & $\begin{array}{l}\text { Community } \\
\text { assemblies in } \\
\text { coordination with } \\
\text { government agencies }\end{array}$ & $\begin{array}{l}\text { Service } \\
\text { delivery }\end{array}$ & $\begin{array}{l}\text { Ricana, } \\
1981^{45}\end{array}$ \\
\hline 1981-1985 & $\begin{array}{l}\text { Case study on primary health care instigated by } \\
\text { the "entry points" approach, focusing on family } \\
\text { planning acceptance, decreasing malnutrition, } \\
\text { and decreasing intestinal helminth infections. }\end{array}$ & Benguet & POPCOM, JICA & $\begin{array}{l}\text { Service } \\
\text { delivery }\end{array}$ & $\begin{array}{l}\text { JOICFP, } \\
1986^{14}\end{array}$ \\
\hline
\end{tabular}




\begin{tabular}{|c|c|c|c|c|c|}
\hline $\begin{array}{c}\text { Year/s of } \\
\text { implementation }\end{array}$ & $\begin{array}{c}\text { Description of } \\
\text { program/intervention }\end{array}$ & $\begin{array}{l}\text { Locale/ scope } \\
\text { of study }\end{array}$ & $\begin{array}{l}\text { Implementing } \\
\text { agency/ies }\end{array}$ & $\begin{array}{l}\text { Type of } \\
\text { PHC policy } \\
\text { reform* }\end{array}$ & $\begin{array}{l}\text { Study (first } \\
\text { author, year } \\
\text { of publication, } \\
\text { citation) }\end{array}$ \\
\hline 1985 & $\begin{array}{l}\text { Case study describing various community-level } \\
\text { interventions (van with audio-visual equipment, } \\
\text { nutrition and parasite control programs, etc.) } \\
\text { that targeted preventive health care }\end{array}$ & $\begin{array}{l}\text { Four villages, } \\
\text { unspecified } \\
\text { location }\end{array}$ & JOICFP & $\begin{array}{l}\text { Service } \\
\text { delivery }\end{array}$ & $\begin{array}{l}\text { Daniel, } \\
1985^{13}\end{array}$ \\
\hline 1986-1992 & $\begin{array}{l}\text { Review of milestones achieved by DOH } \\
\text { in implementing Primary Health Care for } \\
\text { Community Health Development, most notable } \\
\text { of which was the capacitation of NGOs by } \\
\text { providing financial assistance sourced from } \\
\text { funds loaned from the World Bank. }\end{array}$ & National & $\mathrm{DOH}$ & Leadership & $\begin{array}{l}\text { Development } \\
\text { Partners, Inc., } \\
1996^{44}\end{array}$ \\
\hline 1986-2006 & $\begin{array}{l}\text { Review of various national policy interventions } \\
\text { on primary health care, with emphasis on } \\
\text { volunteer worker training and providing access } \\
\text { to medicines }\end{array}$ & National & $\mathrm{DOH}$ & $\begin{array}{l}\text { Service } \\
\text { delivery, } \\
\text { Leadership }\end{array}$ & $\begin{array}{l}\text { Rebullida, } \\
2006^{46}\end{array}$ \\
\hline 1988 & $\begin{array}{l}\text { Case study documenting the development } \\
\text { community-based health system in an } \\
\text { indigenous community (Hanunuo Mangyans) }\end{array}$ & Mindoro & $\begin{array}{l}\text { De La Salle } \\
\text { University, IDRC }\end{array}$ & $\begin{array}{l}\text { Service } \\
\text { delivery }\end{array}$ & $\begin{array}{l}\text { Osteria, } \\
1988^{18}\end{array}$ \\
\hline 1989 & $\begin{array}{l}\text { Case study on the training of community } \\
\text { residents as "diffusers of appropriate } \\
\text { technology in rural reconstruction, health and } \\
\text { literacy." }\end{array}$ & $\begin{array}{l}40 \text { upland and } 18 \\
\text { lowland villages in } \\
\text { Cavite province }\end{array}$ & IIRR & $\begin{array}{l}\text { Service } \\
\text { delivery }\end{array}$ & $\begin{array}{l}\text { Flavier, } \\
1989^{20}\end{array}$ \\
\hline 1992-2001 & $\begin{array}{l}\text { Case study of two LGUs that implemented } \\
\text { cross-cutting policy interventions that helped } \\
\text { produce favorable health outcomes }\end{array}$ & Irosin, Sorsogon & LIKAS, LGU & $\begin{array}{l}\text { Public } \\
\text { policy }\end{array}$ & $\begin{array}{l}\text { Atienza, } \\
2004^{25}\end{array}$ \\
\hline 1994-1996 & $\begin{array}{l}\text { Case study on the ORT health plus scheme } \\
\text { (OHPS), an offshoot of ORT's maternal and } \\
\text { child health program, which included education, } \\
\text { livelihood, and community organizing activities. } \\
\text { The article compared the performance of the } \\
\text { OHPS with that of another similar scheme } \\
\text { implemented in Guatemala. }\end{array}$ & La Union province & ORT & $\begin{array}{l}\text { Universal } \\
\text { coverage, } \\
\text { Service } \\
\text { delivery }\end{array}$ & Ron, $1999^{19}$ \\
\hline 1996-1997 & $\begin{array}{l}\text { Case study on the implementation of the } \\
\text { sustainable community-based reproductive } \\
\text { health/family planning project, which also } \\
\text { included control of helminthiasis and livelihood } \\
\text { projects }\end{array}$ & Batangas, Capiz & $\begin{array}{l}\text { DOH, UNFPA, } \\
\text { JOICFP }\end{array}$ & $\begin{array}{l}\text { Service } \\
\text { delivery }\end{array}$ & $\begin{array}{l}\text { JOICFP, } \\
1997^{15}\end{array}$ \\
\hline 1998 & $\begin{array}{l}\text { Case study of community volunteer health } \\
\text { workers assisting the local government unit in } \\
\text { implementing national health programs and } \\
\text { responding to local health needs }\end{array}$ & Balayan, Batangas & JOICFP & $\begin{array}{l}\text { Service } \\
\text { delivery }\end{array}$ & $\begin{array}{l}\text { Arroyo, } \\
1998^{43}\end{array}$ \\
\hline 1999 & $\begin{array}{l}\text { Case control study investigating the } \\
\text { relationship between the presence of three } \\
\text { types of community-managed drug stores and } \\
\text { household access to medicines }\end{array}$ & Cavite province & $\begin{array}{l}\text { Local government } \\
\text { units }\end{array}$ & $\begin{array}{l}\text { Service } \\
\text { delivery }\end{array}$ & Flores, $2001^{42}$ \\
\hline 2001 & $\begin{array}{l}\text { Review of the health outcome performance of } \\
\text { Sentrong Sigla-certified health facilities was } \\
\text { compared with non-certified facilities }\end{array}$ & National & $\mathrm{DOH}$ & $\begin{array}{l}\text { Service } \\
\text { delivery }\end{array}$ & $\begin{array}{l}\text { Catacutan, } \\
2005^{24}\end{array}$ \\
\hline 2002 & $\begin{array}{l}\text { Survey comparing healthcare utilization among } \\
\text { member and non-member households in a } \\
\text { micro health insurance unit scheme. }\end{array}$ & $\begin{array}{l}\text { Six MIUs: } \\
\text { Guimaras; } \\
\text { Davao City; } \\
\text { Quezon City; } \\
\text { San Fernando, La } \\
\text { Union; Bayawan, } \\
\text { Negros Oriental; } \\
\text { Valenzuela City }\end{array}$ & $\begin{array}{l}\text { LGU (Guimaras), } \\
\text { cooperatives (Davao, } \\
\text { Quezon City), NGO } \\
\text { (La Union), local } \\
\text { hospital (Bayawan) }\end{array}$ & $\begin{array}{l}\text { Universal } \\
\text { coverage }\end{array}$ & Dror, $2005^{21}$ \\
\hline
\end{tabular}

Notes:

${ }^{*}$ As defined by the 2008 WHR: 1) service delivery, 2) leadership, 3) public policy, 4) universal coverage

${ }^{\wedge} T$ The Department of Health was formerly known as the Ministry of Health during the Marcos administration.

Acronyms: DOH-Department of Health, IDRC-International Development Research Centre, IIRR-International Institute for Rural Reconstruction, JICA-Japan International Cooperation Agency, JOICFP-Japanese Organization for International Cooperation in Family Planning, LIKAS-Lingap para sa Kalusugan ng Sambayanan, LGU-local government unit, MIU-micro health insurance unit, NGO-non-government organization, OHPS-ORT health plus scheme, ORT-Organization for Education Resources and Training, POPCOM-Commission on Population, UNFPA-United Nations Population Fund. 
health facilities and promoting acceptance to different health programs. ${ }^{16} \mathrm{~A}$ key issue in the training of health workers was their level of literacy, as well as their voluntary engagement which did not entitle them to compensation and other benefits. Nonetheless, the training and deployment of volunteer health workers increased local acceptance of health programs, and therefore, helped address health needs and improve health indicators.

These improvements were made possible by the collaboration of NGOs with local authorities and communities in the 1960s and 1970s, leading to the formation of community-based health programs (CBHPs), which still continues to this day in different far-flung regions in the country. NGOs that were involved in community medical activities were voluntary professional groups and health activists, which included the Kabataang Makabayan (Patriotic Youth) and Progresibong Kilusang Medikal (Progressive Medical Movement) in the 1960s, and in the 1970s, the Council for Primary Health Care, Council for Health Development, Medical Action Group, and Pangkalusugang Lingkod Bayan (Civil Servants for Health). ${ }^{17}$ Other agencies that collaborated with communities which were described in the literature included academic institutions such as the Davao Medical School Foundation and De La Salle University; international NGOs such as the Organization for Education Resources and Training (ORT) and the International Institute for Rural Reconstruction; and faith-based groups such as the Rural Missionaries of the Philippines, the National Secretariat for Social Action of the Catholic Bishops' Conference of the Philippines, and the National Ecumenical Health Concerns of the National Council of Churches in the Philippines, with funding from counterparts in Germany and the Netherlands. International cooperation agencies, especially those of the Netherlands and Japan, were also important sources of funding and technical assistance. ${ }^{11,17-20}$ The concerted effort of the aforementioned stakeholders paved the way for the mainstreaming of the $\mathrm{PHC}$ approach as a health service delivery strategy, initially in individual local government units (LGUs), and eventually on a national scale.

\section{Universal coverage reforms}

Providing "universal coverage" in its current sense as a means for financial risk protection was not a prominent intervention in the early years of the PHC approach, but it emerged as an offshoot of an effort to improve means of livelihood of families covered by CBHPs. As with service delivery reforms, universal coverage efforts were mostly introduced by NGOs such as the ORT, and local cooperatives. ${ }^{19,21} \mathrm{~A}$ remarkable feature of these insurance schemes was that theywere mostly accessed through voluntary membership and regular contributions. Entitlements and benefits varied across these schemes, with one scheme being similar to a private health maintenance organization, where membership provides exclusive access to accredited health professional services and hospital facilities, as in the case of the ORT Health Plus Scheme (OHPS), which was operated in La Union province. ${ }^{19}$ There was not any mention of how these schemes interacted with the system organized by the Philippine Health Insurance Corporation (Philhealth), which currently relies on insurance premiums and governmentfunded sponsorships, which needs further study.

\section{Leadership reforms}

Most of the studies that documented leadership reforms were case studies on the Philippine government's efforts at nationalizing strategies inspired by the $\mathrm{PHC}$ approach, with roles ranging from providing technical assistance to actively engaging with NGOs and other stakeholders. It is important to note that the inclusion of PHC-influenced strategies in the health leadership agenda were either a means of adhering to international commitments, or scaling up interventions that had been proven successful in addressing communitylevel health needs. Moreover, it is likewise noteworthy that these reforms foreshadowed the eventual implementation of the Local Government Code in 1991, which provided for the fiscal autonomy of local government units, and thus, direct control over health program implementation. ${ }^{22}$

Specifically, engagement with NGOs was a strategy that the government attempted to finance with funding support from international lending agencies (i.e. the World Bank) and foreign cooperation agencies as mentioned previously. ${ }^{17}$ Also, as early as 1979 , the $\mathrm{DOH}$ asserted that its role in PHC is more of providing a "coordinating" role, rather than an active role in encouraging PHC at the community level. ${ }^{23}$ Meanwhile, in the late 1990s, the government transitioned to an accreditation model through which it implemented a standard for health facilities and services that should be met by the devolved local health facilities (i.e. the Sentrong Sigla or Center of Vitality movement), but it was not shown to generate significant improvement in health outcomes in host communities. ${ }^{24}$

\section{Public policy reforms}

Preceding the public policy reforms advocated in the 2008 WHR and the adoption of the "health in all policies" framework of the WHO, local government units in the country have already implemented public policy interventions on the premise that all government sectors contribute to the achievement of favorable health outcomes. The literature provides the case of the municipality of Irosin in Sorsogon, in which public policy reforms involved multiple sectors, taking advantage of the local autonomy that had been granted to LGUs under the Local Government Code of 1991. Particularly, a policy environment favorable to community participation was developed during the term of Mayor Eddie Dorotan, who had been a doctor working with the NGO Lingap para sa Kalusugan ng Sambayanan (Care for the People's Health) and who had spearheaded the creation of CBHPs in the municipality. Through his leadership and 
experience in running CBHPs and other similar health programs, he increased public spending for health care and created venues for the participation of NGOs in the affairs of municipal government, which had already been organized and empowered to engage with government and other stakeholders. ${ }^{25}$

\section{DISCUSSION}

The choice to use the set of reforms proposed by the 2008 WHR as an analytical framework to appraise the available literature comes from the desire to assess whether the reforms promoted by the WHR parallel factors that contributed to the success of the PHC approach in the Philippines, as well as the need to analyze factors to consider in carrying out each of the proposed reforms for the rest of country. While the success stories of PHC in the country are encouraging, it must be pointed out that these successes were limited to specific locales, and thus did not represent the general healthcare situation in the country, which is beyond the scope of this article. ${ }^{26}$ However, to understand how the achievements documented in the studies indeed contributed to the evolution of PHC in the country, there is a need to understand the historical and cultural context surrounding the reforms undertaken towards achieving primary health care in the community level.

Being in a country with persisting social inequalities, communities in economically depressed or geographically isolated areas have been vulnerable to economic problems, which have led to lack of livelihood, and insufficient resources for food and other basic needs. These conditions, which have been considered part of the social determinants of health (SDH), have been proven to contribute to poor health that further incapacitates individuals and sets into motion a vicious cycle of worsening poverty and illness. ${ }^{27}$ The studies suggest that this vulnerability, further complicated by a communal sense of socioeconomic and political powerlessness, can only be surmounted by interventions that allow communities to break the aforementioned vicious cycle that would otherwise bind them to a lifetime of poverty and disease. These interventions, which should afford opportunities for economic productivity, access to basic health services and social advancement, can only be carried out by "the participation of all social classes," while ensuring that programs are "designed, implemented, run by and belong to the people of the community."27,28

This was the goal of community empowerment, which in the 1950s and succeeding decades was often achieved by communities through the support of health and developmentoriented NGOs. Interventions that were considered precursors to the PHC approach include training and livelihood programs on health, as well as agriculture, education, and livelihood, which eventually led to an intentional effort to organize communities and address root causes to persistent health problems, which were often related to lack of economic opportunities. ${ }^{29} \mathrm{PHC}$ thus evolved in the country to address the lack of health services and economic opportunities that would ordinarily be provided by government, culminating in its global popularity as an approach endorsed by the WHO during its Alma Ata Conference in 1978.

Subsequently, the government exerted effort to uphold its commitment by transitioning from a national health system that segregated preventive health services and curative services to a district health system that gave attention to public health concerns as well as primary care services at the community level..$^{30}$ However, by designing these interventions to fit the disease-oriented selective primary care model, the government chose to limit its PHC efforts to health promotion and increasing access to communitylevel health services, stopping short of promoting community empowerment in imitation of successful NGO-initiated efforts. This reluctance may well be understandable, as it coincided with the global shift to selective primary health care in light of the considerable national and global political instability in the latter half of the $20^{\text {th }}$ century. ${ }^{3,30}$

In what may now be considered as an artful strategy, amid the continued poor health status in disadvantaged areas in the decades that followed, the literature showed how NGOs adjusted to this disease-centric approach by focusing on a specific disease or health issue prevalent in a host community, and gradually enlarging the scope of intervention to such a degree that it ultimately targeted to address the root causes of prevailing health problems. The most commonly targeted health issues that enabled this approach were maternal and child health, specifically family planning, which had the unique advantage of being a priority program for international technical assistance agencies and foreign funding, while also equipping women to make lifestyle choices that promoted social advancement. ${ }^{3,31}$ This empowerment eventually paved the way for the development of economic interventions reminiscent of the community empowerment strategies that were pioneered in the 1960s, but with the added value that health performance indicators were also targeted.

In the interim, the health system struggled in the transition caused by the 1991 Local Government Code (LGC), which delegated health service delivery to the local government units and, reminiscent of the PHC promotion strategy in the late 1970s, assumed the responsibility of coordination and technical support to LGUs in providing community-level health services. As shown by the public policy reform exemplified in Irosin, Sorsogon, local autonomy has empowered local chief executives in implementing interventions that are suitable for local health needs, but at the expense of implementation standards that would ideally apply to all LGUs. ${ }^{22,25,32}$ It must be noted that while the DOH maintained its role in implementing standards, due to the LGC devolving the employment of health workers to LGUs, it has inevitably rendered health workers beholden to the interests of local government political figures, which ideally should not affect the provision of health services and addressing health problems and their root causes. ${ }^{32}$ 
In the setting of a decentralized health system, the $\mathrm{DOH}$ has since relied on public policy, monitoring, evaluation, technical support, and advocacy in pushing for improvement of national health outcomes, its efforts being shaped by the 1999 Health Sector Reform Agenda (HSRA) as well as international frameworks. ${ }^{33,34}$ The HSRA implemented changes such as the strengthening of health regulation, local health system development, expansion of Philhealth coverage, integration of public health services, and giving fiscal autonomy to government hospitals. ${ }^{33,34}$ Meanwhile, the renewed PHC definition of the 2008 WHR, as well as other frameworks such as the WHO six building blocks framework for health systems, has shaped its operational goals, which have taken on various incarnations with each passing presidential administration. ${ }^{35}$ These goals have commonly adopted a disease-oriented approach, but in recent decades, having been influenced by the sweeping changes of the HSRA, increasing emphasis has been given to operational efficiency, health system responsiveness, and the prevention of catastrophic health expenditure. Having been influenced by the health goals of preceding administrations, the current administration has adopted three national guarantees that make up its Philippine Health Agenda: the development of service delivery networks, financial risk protection, and an approach that targets the triple burden of disease (communicable diseases, non-communicable diseases and nutrition, and diseases of urbanization and industrialization) across the life stages. These guarantees are targeted through a set of goals summarized as "ACHIEVE," which are as follows:

1. Advance quality, health promotion and primary care

2. Cover all Filipinos against health-related risk

3. Harness the power of strategic HRH development

4. Invest in eHealth and data for decision-making

5. Enforce standards, accountability and transparency

6. Value all clients and patients, especially the poor, marginalized, and vulnerable

7. Elicit multisectoral and multistakeholder support for health. ${ }^{36}$

Admittedly, though these guarantees can still be considered disease-oriented and targeted to individuals rather than communities, the inclusion of financial risk protection recognizes the importance of economic sufficiency in achieving an ideal state of health, thereby aiming to fulfill the PHC ideal of equitable access. It also acknowledges that in order to sustainably improve health outcomes, the $\mathrm{DOH}$ must enlist the support of other sectors in addressing root causes of health problems. However, since this is a strategy targeted to health decision makers and local governments, it reasonably limits itself to approaches that are doable within the operational scope of its intended audience.

Notwithstanding, as the reviewed studies showed, the sustainability that is sought by these guarantees and strategies can be better attained by promoting community empowerment, that is, by capacitating and organizing communities to develop self-reliance and assert selfdetermination in addressing root causes that bind them to the vicious cycle of poverty and worsening health. It remains a challenge, nevertheless, to operationalize this ideal in the current health system, which emphasizes accountability within a bureaucratic policy environment.

Scaling up the idea of community empowerment may require adopting an evaluator perspective, which proposes that this effort should begin with a community-level framework for development that differentiates between "aspects of empowerment that are considered of direct value, that is, as ends in themselves, and those that are means to an end." ${ }^{37}$ Focusing on agent-specific empowerment, four key elements have been identified: 1) access to information, 2) inclusion, 3) accountability, and 4) local organizational capacity. If the goal is to monitor community empowerment as a public healthrelated objective, the government should identify community empowerment metrics in a manner similar to evaluating, for instance, maternal mortality rate as an indicator for maternal health, or contraceptive prevalence rate as a measure of a successful family planning advocacy. In the latter case, the action is the family planning advocacy, and the desired end is contraceptive prevalence. The causal relationship between the action and the desired end must be clarified, especially since the success of health interventions is often measured by key performance indicators.

An approach that may aid in identifying the action and the desired end is the "most significant change" methodology, in which changes in health outcomes are documented, and are contextualized by asking "who did what, when, why, and why it was important." ${ }^{38}$ This method should also account for all forces, stakeholders, and variables that may potentially affect the interventions that intend to empower communities, as well as the communities' idea of empowerment itself. This idea of empowerment may eventually be assessed within a "spectrum of responsibilities," that includes these levels: 1) information, 2) consultation, 3) responsible accountability, 4) collective choice, and 5) service control. This continuum has been proposed in the Philippine setting by categorizing CBHPs as either "community-oriented," "community-based," or "community-managed," but in order to fully integrate the principles of PHC in the current public health system, this evaluation needs to be made part of standard health status evaluations that are used to assess communities being served by the public health system..$^{39,40}$

Additionally, from a public policy perspective, Irosin's example also showed that success in local health initiatives are reliant on the inclusion of public health as one of the stated goals of local leadership, which may not be possible in all local governments given the wide array of political and socioeconomic interests which local chief executives may choose to prioritize. ${ }^{25,32}$ Therefore, this emphasizes that in order to address health problems regardless of public policy priorities, there is a need to increase the sensitivity of politicians and bureaucrats to SDH, and how its components 
may be addressed in non-health sectors, a premise that is upheld by the "health in all policies framework," which recognizes that holistic development redounds to better health. ${ }^{10}$ This increase in awareness on $\mathrm{SDH}$ should also be coupled by promoting $\mathrm{NGO}$ and civic society participation in government affairs. ${ }^{41}$

Furthermore, an aspect of PHC that has received less attention in the gathered literature is that health interventions should be "scientifically sound." Interestingly, one study included in the review critically analyzed a key communitylevel public health intervention, the establishment of community-managed drug stores (Botika ng Barangay or $\mathrm{BnBs}$ ), a study of which suggested that the presence of $\mathrm{BnBs}$ led to incorrect use of medicines in communities. ${ }^{42} \mathrm{In}$ view of this concern, this therefore shows how government should strike a balance between regulating and standardizing public health interventions initiated by NGOs, and creating a policy environment that promotes community participation and empowerment.

Finally, the relative paucity of available literature on CBHPs and PHC efforts highlights the importance of documenting the conduct of community-based interventions, as a way to assess the way by which these interventions follow the PHC approach and, by their contribution to the body of knowledge on PHC implementation in the country, to help improve community-level health interventions in the Philippines.

\section{CONCLUSION AND RECOMMENDATIONS}

Results of the systematic review show that the evolution of $\mathrm{PHC}$ in the Philippines predated the formal definition of PHC, but has taken on an approach that focused on diseaseoriented interventions. Nevertheless, the studies included in the review, which document the evolution of PHC as an approach to achieving community health, pinpoint the persistent need for national level public health interventions to be targeted to community health and social determinants of health as well as individual health, with the assumptions that good community-level health care and holistic development can redound to good national health outcomes, and that ideal community health and development can only be attained by participation and empowerment. It is therefore recommended that standard metrics for community empowerment should also be developed and implemented by government, in order to ensure sustainable health and development, and the scientific validity of community health interventions.

\section{Acknowledgments}

The authors would also like to thank Jeffrey L. Flores, Charlyn M. Maybituin, Lavinia A. Oliveros, and Sahreen Dee F. Tumbagahan for their assistance in the preparation of the manuscript, and the journal reviewers for their helpful comments.

\section{Statement of Authorship}

All authors approved the final version submitted.

\section{Author Disclosure}

All authors declared no conflict of interest.

\section{Funding Source}

This work was supported by the University of the Philippines Emerging Interdisciplinary Research Program under the Office of the Vice President for Academic Affairs under Grant C3-007.

\section{REFERENCES}

1. World Health Organization (WHO), Declaration of Alma-Ata [Online]. 1978 [cited 2016 Dec]. Available from http://www.who.int/ publications/almaata_declaration_en.pdf?ua $=1$.

2. Dickerson C, Grills N, Henwood N, Jeffrey S, Lankester T. The World Health Organization engaging with civil society networks to promote primary health care: a case study. Glob Health Gov. 2012; 6(1):1-13.

3. Cueto $M$. The origins of primary health care and selective primary health care. Am J Public Health. 2004; 94(11):1864-74.

4. Magnussen L, Ehiri J, Jolly P. Comprehensive versus selective primary health care: lessons for global health policy. Health Aff. 2004; 23(3):167-76. doi: 10.1377/hlthaff.23.3.167.

5. Braveman P, Gottlieb L. The social determinants of health: it's time to consider the causes of the causes. Public Health Rep. 2014; 129(Suppl 2):19-31. doi:10.1177/00333549141291S206

6. World Health Organization (WHO). From Alma-Ata to the year 2000, Reflections at the midpoint. Geneva: World Health Organization; 1988.

7. Chowdhury Z, Rowson M. The People's Health Assembly. BMJ. 2000; 321(7273):1361-2.

8. Declaration on "Health care for all." Int J Health Plann Mgmt 2003; 18:S103-6. doi:10.1002/hpm.728.

9. WHO. The World Health Report 2008: primary health care (now more than ever.) [Online]. 2008 [cited 2017 Aug]. Available from http://www.who.int/whr/2008/en/.

10. WHO and Ministry of Social Affairs and Health, Finland. The Helsinki statement on health in all policies. 2013 [cited 2017 Aug]. Available from www.who.int/healthpromotion/conferences/8gchp/8gchp_ helsinki_statement.pdf.

11. Angeles JI. Katiwala program: an alternative solution to the health problem [Abstract]. Popul Forum. 1981; 7(3):2-6.

12. Marfil MP. Sarikaya: Toward community selfreliance in health and family planning [Abstract]. Initiatives in Population. 1979; 5(3):203.

13. Daniel C, Mora B. The integrated project: a promising promotional strategy for primary health care. JOICFP Rev. 1985; 10:20-7.

14. A Philippine experiment in community development [Abstract]. JOICFP Rev. 1986; 11:6-11.

15. Developing a model project. JOICFP's project in the Philippines is serving as a model of communitybased activities [Abstract]. JOICFP News. 1997; (272):1.

16. Lacuesta M, Sarangani S, Amoyen N. A diagnostic study of the DOH health volunteer workers programme [Abstract]. Philipp Popul J. 1993; 9(14):2636.

17. Encarnacion Tadem TS. The role of non-governmental organizations in the field of health in modern Southeast Asia, the Philippine experience. In: Harper T, Amrith SS, eds. Histories of health in Southeast Asia: Perspectives on the long twentieth century. Bloomington, Indiana: Indiana University Press; 2014. pp.222-36.

18. Osteria TS, Okamura JY. Community based health care in the Philippine highlands: the Hanunuo Mangyans of Mindoro. Asia Pac J Public Health 1998; 2(4):230-4.

19. Ron A. NGOs in community health insurance schemes: examples from Guatemala and the Philippines. Soc Sci Med. 1999; 48(7):939-50. 
20. Flavier J. Gaining intersectoral support: the case of the People's School [Abstract]. Hygie. 1989; 8(1):21-5.

21. Dror D, Soriano ES, Lorenzo ME, Sarol JN Jr, Azcuna RS, Koren R. Field based evidence of enhanced healthcare utilization among persons insured by micro health insurance units in Philippines. Health Policy. 2005; 73(3):263-71. doi:10.1016/j.healthpol.2004.11.018.

22. Grundy J, Healy V, Gorgolon L, Sandig E. Overview of devolution of health services in the Philippines. Rural Remote Health. 2003; 3(2):220.

23. Bautista V. Status report on primary health care (1987-1993). In: Book of readings on primary health care. Diliman: College of Public Administration, University of the Philippines Diliman; 1996. pp.31-52.

24. Catacutan AR. The health service coverage of quality-certified primary health care units in Metro-Manila, the Philippines. Health Policy Plan. 2006; 21(1):65-74. doi: 10.1093/heapol/czj006.

25. Atienza ME. The politics of health devolution in the Philippines: Experiences of municipalities in a devolved set-up. Philippine Political Science Journal. 2004; 25(48):26-54.

26. Phillips DR. Primary health care in the Philippines: banking on the barangays [Abstract]? Soc Sci Med. 1986; 23(10):110517.

27. De Vos P, De Ceukelaire W, Malaise G, Pérez D, Lefèvre P, Van der Stuyft P. Health through people's empowerment: a rights-based approach to participation. Health Hum Rights. 2009; 11(1):23-35.

28. Romualdez A. Primary health care [Abstract]. Maghreb Med. 1980; 20(4):3-4.

29. Morgan LS. Community development: observation around the world. Am J Public Health Nations Health. 1965; 55(4):607-12.

30. Roemer MI. Political ideology and health care: hospital patterns in the Philippines and Cuba. Int J Health Serv. 1973; 3(3):487-92. doi:10.2190/F1LQ-VFD5-U33C-QW7Q.

31. David F, Chin F, Herradura E. Economic and psychosocial influences of family planning on the lives of women in western Visayas [Online]. 1998 [cited 2017 Aug]. Available from http://pdf.usaid.gov/pdf_docs/ Pnach128.pdf.

32. Bossert TJ, Beauvais JC. Decentralization of health systems in Ghana, Zambia, Uganda and the Philippines: a comparative analysis of decision space. Health Policy Plan. 2002; 17(1):14-31.

33. Priela JO Jr. Health sector reform agenda in the Philippinesits effect on private hospitals [Abstract]. World Hosp Health Serv. 2001; 37(2):22$4,33,35$.
34. Solon O,Panelo C, Gumafeliz E. A review of the Health Sector Reform Agenda (HSRA) implementation progress [Online]. 2003 [cited 2017 Aug]. Available from http://pdf.usaid.gov/pdf_docs/Pnacu519.pdf.

35. WHO. The WHO health systems framework [Online]. 2017 [cited 2017 Aug]. Available from http://www.wpro.who.int/health_services/ health_systems_framework/en/.

36. Department of Health. All for health towards health for All: Philippine health agenda 2016-2022 [Online]. 2016 [cited 2016 Dec]. Available from http://www.doh.gov.ph/sites/default/files/basic-page/ Philippine\%20Health\%20Agenda_Dec1_1.pdf.

37. Khwaja A. Measuring empowerment at the community level: an economist's perspective. In: Measuring empowerment: crossdisciplinary perspectives. Washington DC: The World Bank; 2005. pp.267-84.

38. Polet F, Malaise G, Mahieu A, et al. Empowerment for the right to health: the use of the "most significant change" methodology in monitoring. Health Hum Rights. 2015; 17(2):71-82.

39. Galvez Tan, J. Primary health care in the hands of the people. In: Book of readings on primary health care. Diliman: College of Public Administration, University of the Philippines; 1996. pp.1-15.

40. Dickinson S, Prabhakar M. An analytical framework for community empowerment evaluations [Online]. London: Department for Communities and Local Government, Government of the United Kingdom; 2009 [cited 2017 Aug]. Available from http://www.sqw. co.uk/files/4313/8712/7616/48.pdf.

41. Ramiro LS, Castillo FA, Tan-Torres T, et al. Community participation in local health boards in a decentralized setting: cases from the Philippines. Health Policy Plan. 2001; 16(Suppl 2):61-9.

42. Flores FP, Umenai T, Wakai S. Should community-managed drug stores be phased out? Asia Pac J Public Health 2001; 13(1):9-12.

43. Arroyo A. We work for the barangay where we live [Abstract]. Integration. 1998; (55):52.

44. Development Partners, Inc. A rapid appraisal of the PCHD. In: Book of readings on primary health care. Diliman: College of Public Administration, University of the Philippines; 1996. pp.16-30.

45. Ricana C. Two models on primary health care approach of Region VII [Abstract]. Maghreb Med. 1981; 21(1):17-8.

46. Rebullida L. The Philippine commitment to primary health care: policy directions. Public Policy. 2006; 10(1):122-47. 